
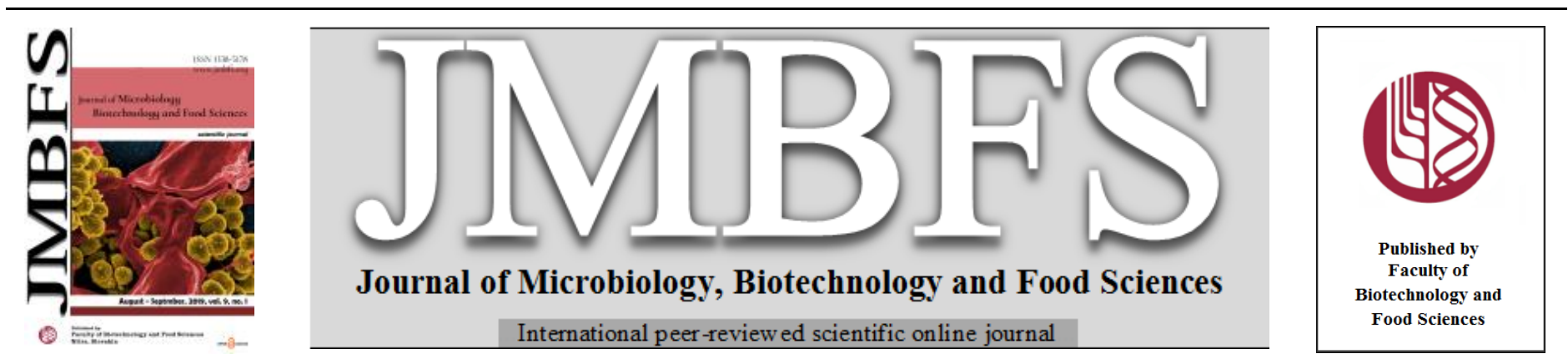

\title{
FISSION YEAST SCHIZOSACCHAROMYCES POMBE AS A MODEL SYSTEM FOR ULTRASTRUCTURAL INVESTIGATIONS USING TRANSMISSION ELECTRON MICROSCOPY
}

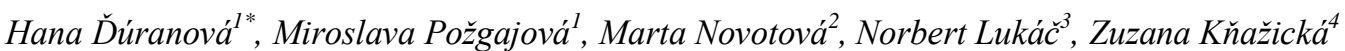

\section{$\operatorname{Address}(e s)$ :}

${ }^{1}$ Slovak University of Agriculture in Nitra, AgroBioTech Research Centre, Tr. A. Hlinku 2, 94976 Nitra, Slovak Republic.

${ }^{2}$ Biomedical Research Center, Slovak Academy of Sciences, Dúbravská cesta 9, 84505 Bratislava, Slovak Republic.

${ }^{3}$ Slovak University of Agriculture in Nitra, Faculty of Biotechnology and Food Sciences, Department of Animal Physiology, Tr. A. Hlinku 2, 94976 Nitra, Slovak Republic.

${ }^{4}$ Slovak University of Agriculture in Nitra, Faculty of Biotechnology and Food Sciences, Tr. A. Hlinku 2, 94976 Nitra, Slovak Republic.

*Corresponding author: hana.duranova@uniag.sk

doi: 10.15414/jmbfs.2019.9.1.160-165

\section{ARTICLE INFO}

Received 1. 4. 2019

Revised 21. 6. 2019

Accepted 24. 6. 2019

Published 1. 8. 2019

Review

open $\bigodot_{\text {ACCESS }}$

\begin{abstract}
The unicellular fission yeast Schizosaccharomyces pombe (S. pombe) has become a prominent model system to elucidate a various range of biological processes which are highly conserved in mammalian cells. Ultrastructure of the cells related to the organelle morphology is useful in the generation of the comprehensive overview of the cell function. Transmission electron microscopy provides a unique tool to study cell architecture under physiological conditions, as well as ultrastructural changes of the cells due to toxic or beneficial effects of diverse additives. In recent years, $S$. pombe has also proved to be a suitable cell system for transmission electron microscopy investigations. In the current study, general features of $S$. pombe are described. In addition, conventional specimen preparation technique and the important discoveries of cell architecture emerging from transmission electron microscopy studies of $S$. pombe are summarized.
\end{abstract}

\section{INTRODUCTION}

In the most common terms, a model organism is defined as a non-human biological subject used in scientific laboratories to investigate specific biological processes and mechanisms under physiological or experimental conditions. In this regard, it is believed that findings and theories made in the model organism can be applied to higher species that are expected to be more complex than the model system (Ankeny and Leonelli, 2011). According to Al-Wattar (2017), the criteria for a model biological system are as follows: (i) the used organism should be easy to obtain, grow and manipulate; (ii) its operation size should be convenient; (iii) it should be inexpensive to maintain; (iv) the model organism should have short life cycle; (v) the organism can be genetically modified, and (vi) it should have the potential to deliver economically important results.

\section{GENERAL CHARACTERISTICS OF MODEL SYSTEM SCHIZOSACCHAROMYCES POMBE}

Yeasts are single-celled (unicellular) eukaryotic organisms characterized by easy manipulation, low-cost cultivation demands, and short life cycle allowing researchers to study fundamental biological properties. They are harmless, genetically amendable with one of the smallest genomes permitting wholegenome characterization of various cell processes (Zhao, 2017). Additionally, they possess basically the same subcellular structure as cells of higher organisms (animals and plants) venturing their use as a laboratory tool for basic and applied spheres of biology, life science, medicine, or biotechnology (Osumi, 2012).

Schizosaccharomyces pombe (S. pombe), often known simply as "fission yeast" is a unicellular eukaryote belonging to the Ascomycetes which are characterized by formation of sexual spores inside an ascus (Latin for "bag"; Hoffman et al., 2015). Saare and colleagues isolated the fission yeast from a millet beer which was contaminated due to its delaying journey from East Africa to Europe (Germany). Isolation of the pure $S$. pombe culture followed by its first detailed description was done in early 1890s by Ziedler and his supervisor Paul Lindner (Hayles and Nurse, 2018). In general, pombe is the Swahili word for "beer" (or at least a beer-like fermented beverage), and the fission yeast is used for its fermentation (Hoffman et al., 2015). Besides this, S. pombe often occurs within the process of molasses fermentations during preparation of distilled commodities such as rum, arrak, tequila or cachaca (Gomes et al., 2002) and is known for its ability to utilize malic acid resulting in elimination of undesirable acidity in wine (Volschenk et al., 2003; Benito et al., 2016).

From morphological point of view, the fission yeast cell (Figure 1) has a cylindrical rod shape of $4 \mu \mathrm{m}$ in diameter (Piel and Tran, 2009) lined by a cell wall which mainly consists of polysaccharides directly responsible for cell wall rigidity (Grün et al., 2004). In 1977, Manners and Meyer (Manners and Meyer, 1977) determined the exact composition of the cell wall as follow: $9-14 \% \alpha-$ galactomannan, 18 - $28 \% \alpha$-1,3-glucan, $42 \% \beta-1,3$ glucan and $2 \% \beta-1,6-$ glucan. The exoskeletal rigid structure (representing $\sim 20 \%$ of the cell dry mass) is required for survival of $S$. pombe due to its protective efficacy against cell destruction caused by an increased internal turgor pressure or external mechanical injuries. Deeper understanding of the cell wall structure and composition will bring a valuable insight in $S$. pombe morphogenetic specifications, as the cell wall also defines the shape of the cells (Pérez and Ribas, 2017). Moreover, the protoplasts of the fission yeast are able to fully restore cell walls in liquid media, thereby reverting to normal cells. This feature of the regenerating process makes $S$. pombe a useful tool to analyze a process of de novo synthesis of the cell wall (Osumi, 2012).

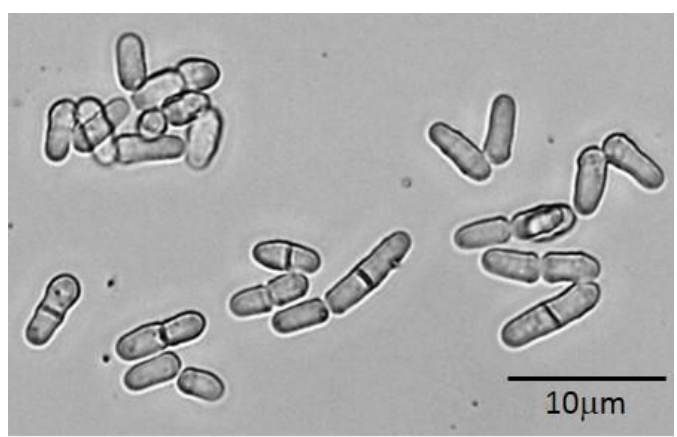

Figure 1 Representative microphotograph of $S$. pombe cells 
Visualized are bright field images of vegetative wild type cells under inverted DM IL LED Leica microscope, equiped with Leica EC3 digital color camera, magnification 40x.

The growth of fission yeast cells is commonly established through the cell ends elongation in a linear polarized fashion ensuring their typical cell morphology (Grün et al., 2004). Schizosaccharomyces pombe grows by elongation from 7 to $14 \mu \mathrm{m}$ in length (Piel and Tran, 2009). During mitotic cell division, the cell growth is ceased. Hence, the cell length serves as a sensitive cell cycle phase indicator of the analyzed cells, and additionally, cell size monitoring facilitates an evaluation of the timing of mitotic entry (Forsburg and Rhind, 2006; Hagan $\boldsymbol{e}$ al., 2016). Compared to other eukaryotic species, $S$. pombe grows quickly. Under normal conditions, a wild-type cell takes about $2.5-3 \mathrm{~h}$ to complete a cell cycle which is similar to that of other eukaryotes (i.e., it also includes G1, S, G2 and M phases; Gómez and Forsburg, 2004). Schizosaccharomyces cells divide by medial fission (Hayles and Nurse, 2018) followed by cleavage of the primary septum (Peckys et al., 2011). This cell division is morphologically very symmetric and thus results in a formation of two almost identic daughter cells (Lin and Austriaco, 2014). Besides asexual multiplying through the mitotic cycle, the cells can mate and form diploid zygotes. Sporulation immediately follows meiosis resulting in the production of four round or oval haploid ascospores enclosed within an ascus (Zhao, 2017). Mating in S. pombe occurs under conditions of nutritional stress (Martín et al., 2013). Differentiation into a variety of filamentous or hyphal growth forms is also feasible in the fission yeasts (Amoah-Buahin et al., 2005).

Regarding genetic features, the genome of $S$. pombe was fully sequenced in 2002 becoming the sixth model eukaryote with entire sequenced genome (following Saccharomyces cerevisiae, Caenorhabditis elegans, Drosophila melanogaster, Arabidopsis thaliana, and Homo sapiens; Yanagida, 2002). The fission yeast has the smallest sequenced eukaryotic genome (13.8 Mb; Wood et al., 2002) organized into only three chromosomes of 5.6, 4.8 and $3.6 \mathrm{Mb}$, respectively (Hayles and Nurse, 2018). It has single copy genes making it advantageous for gene functional studies. Moreover, its large repetitive centromeres $(40-100 \mathrm{~kb})$ are similar to those of mammals (Roque and Antony, 2010)

The unfussiness in growing, amenability to genetic manipulations, and regular cell size have made $S$. pombe a popular model organism for the study of number major topics in cell biology such as cell cycle (Hagan et al., 2016), cell division (Piel and Tran, 2009), chromosome segregation (Kovacikova et al., 2013 Pozgajova et al., 2013; Yamashita et al., 2017), cell growth conditions (Petersen and Russell, 2016), cell morphology (Huang et al., 2003), cell wall biosynthesis (Leon et al., 2013), the cytoskeleton (Kovar et al., 2011), and many others.

\section{CONVENTIONAL PREPARATION OF S. POMBE FOR TRANSMISSION ELECTRON MICROSCOPY}

In general, ultrastructural studies of various biological samples including $S$. pombe by transmission electron microscopy (TEM) require transformation of the living cells from their native, hydrated state to a dry one that reliably maintains the structural and biological relationships. Four basic conditions must be complied during sample preparation: (i) to prevent destruction of the cell structures and organelles due to vacuum in the electron microscope; (ii) to generate ultra-thin sections in order to eliminate multiple electron scattering (iii); to minimize structural alterations caused by the electron beam; (iv) to maximize the contrast in the object-defined resolution (Slayter and Slayter, 1992 Böttcher, 2012). Taken together, the main aim of the sample processing for TEM is to ensure production of sufficiently thin sections that allow transmission of electron beam through the sample to obtain an image. Hence, construction of thin sections requires three main approaches of sample preparation: fixation in the first step, followed by dehydration, and finished by infiltration/embedding (Wright, 2000)

\section{Growth conditions and harvesting of $S$. pombe}

The difficulty of the yeast cell processing for TEM analysis compared to higher eukaryotic cells lies in the presence of the thick cell wall acting as an obstacle against fixative diffusion (Bauer et al., 2001). To minimize this refractory feature of the $S$. pombe cells to preservation, it is necessary to precisely regulate culture conditions of yeasts. Indeed, recommended timing for fixation of yeast cells is the early log phase which is characterized by minimal density of the cell cytoplasm and maximal cell wall permeability (Wright, 2000; Sipiczki, 2016) In this phase, cell density is limited to $5 \times 10^{6} / \mathrm{ml}$ (i.e., $\mathrm{OD}_{600}=0.5$ ). On the other hand, cells in the stationary phase possess large, electron-dense vacuoles and numerous electron-dense inclusion bodies that obscure ultrastructural details (Wright and Rine, 1989). To ensure that cells are really growing exponentially, it is recommended that cultures have been maintained at a low density $(<0.5)$ for three or more generations (Mulholland and Botstein, 2002).

The average life cycle of $S$. pombe lasts $2-4$ hours at $30{ }^{\circ} \mathrm{C}$ which represents optimal growth temperature in the laboratory. Standard and the most widely used culture medium is rich medium (Standard Yeast Extract with Supplements - YES medium) containing all nutrients such as yeast extract and glucose in excessive amounts, and specific amino acids or nucleobases. This medium with no addition of antibiotics is normally used for yeast growth without selection (Petersen and Russell, 2016; Zhao, 2017).

During cell harvesting it is essential to keep cells as intact as possible forming a compact firm mass (Sipiczki, 2016). In the case of fission yeasts, cell isolations by centrifugation (Bauer et al., 2001; Roque and Antony, 2010; Sipiczki, 2016 Koch et al., 2017) or filtration (Petersen and Russell, 2016; Giddings et al., 2017) appear to be the most preferred methods. However, both of them can cause damages to the cells resulting in structural changes. Centrifugation, the most commonly used process of cell harvesting, leads to cytoskeleton and nuclear positioning (Roque and Antony, 2010). Therefore, centrifugation of yeast cells should be carried out after the cells have been chemically fixed. Taking into account this consideration, the first fixative reagent is added as $2 \mathrm{x}$ stock to the medium with the cells (1:1 ratio) and incubated for 5 minutes at room temperature. Subsequently, the cells are gently centrifuged and resuspended in fresh $1 \mathrm{x}$ stock fixative solution to finalize cell preservation as it was previously described by Wright (2000) and Roque and Antony (2010)

\section{Fixation}

Fixation is the first step providing the preservation of the cells in a state as similar as possible to their vital state. It means that fixation must halt potentially destructive autolytic processes to protect cells against disruption during their embedding and sectioning, as well as to ensure morphological stability of the cells exposed to electron beam (Bozzola and Russell, 1999). Generally, three possible approaches of the fission yeast processing are usually used to retain normal structural organization of the cells for successful staining procedures. The first and the most commonly used technique is the fixation by cross-linking. Alternatively, fixation by precipitation or fixation by freezing (i.e., cryofixation) can also be applied (Sipiczki, 2016). Due to requirement of special laboratory facilities related to cryofixation which are often costly and therefore unavailable in many laboratories, the most widely used technique of cell preservation is based on cell treatment with chemicals known as fixatives. Their task is to remove the water content from cell structures composed of proteins, lipids and carbohydrates, thereby enabling stronger connection between molecules responsible for construction of these structures (Özen and Ceylan, 2013).

For ultrastructural analysis, the most popular method of fixation is double fixation in an aldehyde (primary fixation; sometimes called prefixation) followed by secondary (post) fixation in oxidizing agent (Wright, 2000; Mielańczyk et al., 2015; Ayub et al., 2017).

\section{Primary fixation (Prefixation)}

Currently, the monofunctional and bifunctional aldehydes, i.e., formaldehyde ( $\mathrm{HCHO})$ and glutaraldehyde $\left(\mathrm{CHO}-\mathrm{CH}_{2}-\mathrm{CH}_{2}-\mathrm{CH}_{2}-\mathrm{CHO}\right)$, are the most widely and successfully used reagents for primary fixation. These compounds react with amino groups of proteins and macromolecules associated with proteins (e.g., histoproteins associated with DNA or lipoproteins; Bozzola, 2007) to stabilize them by forming inter- and intra-chain crosslinks. However, they demonstrate little, if any, reactivity with lipids (Wright and Rine, 1989).

Having two aldehyde groups at both ends of the molecule, glutaraldehyde (GA) binds strongly proteins (especially those containing amino acids such as lysine, tyrosine, tryptophan, and phenylalanine; Park et al., 2016) causing their irreversible cross-linking. Since GA contains five carbons in its molecular structure and is also uncharged in a solution, its penetration through the cell wall of the yeasts is very slow (Frankl et al., 2015). Usually, it is available in various concentrations ranging from 8 to $70 \%$. For cell fixation, the concentrations from 0.25 to $3 \%$ are commonly used (Wright, 2000). According to many authors (Bauer et al., 2001; Roque and Antony, 2010; Asakawa et al., 2012; Sipiczki, 2016), GA at a concentration of $2 \%$ is extensively employed for yeasts as a prefixative.

Formaldehyde (FA) preserves the structures of the cells via formation of Schiff base intermediates with free amino groups of proteins, thereby stabilizing adjacent proteins (Perkins and McCaffery, 2007). It is typically used at final concentrations ranging from 0.5 to $4 \%$ (Wright, 2000). For electron microscopy, powdered polymerized formaldehyde, i.e., paraformaldehyde (PFA) is used. The small size of PFA and only one aldehyde group permit its rapid diffusion across the cell wall of yeasts (Frankl et al., 2015). However, in spite of deeper and faster penetration, it has a relatively weaker (especially in low concentrations) reversible fixation power as compared to GA (Hajibagheri et al., 1999; Park et al., 2016).

In recent years, GA has begun to be used in conjugation with FA known as Karnovsky's fixative (Karnovsky, 1964). Karnovsky's original fixative (containing $5 \%$ GA and $4 \% \mathrm{FA}$ ) is often modified to yield fixatives with lower concentrations of both FA and GA (e.g., $2 \%$ PFA and $2.5 \%$ GA; Bozzola and Russell, 1999). It is usually employed in difficult to fix biological samples, as well as in those for which a preservation protocol is absent (Bozzola, 2007). The combination of GA with PFA as a fixative for electron microscopy takes advantage of the rapid diffusion of PFA into the cells initializing the structural 
stabilization whilst thorough cross-linking is guaranteed by more slowly penetrating GA (Kiernan, 2000; Wright, 2000). For S. pombe, a combination of $0.5 \% \mathrm{GA}$ and $3 \% \mathrm{PFA}$ in $0.1 \mathrm{M}$ phosphate buffered saline (PBS; pH 7.2) can also be applied. Unfortunately, PFA can negatively affect fixation of ultrastructural components within the cell resulting in a potential reduction of the clarity of several intracellular structures (Sipiczki, 2016).

Although GA and PFA are excellent fixatives for preserving the microstructure of various cells including $S$. pombe, they do not possess enough contrast to stain cell components. Additionally, they have almost no power to fix lipids in biological membranes thus leading to their extraction during dehydration and infiltration. As a result of this process, electron transparent spaces are observed instead of initially localized membranes (Wright, 2000). Therefore, postfixation with oxidizing compounds should be performed.

\section{Secondary fixation (Postfixation)}

The most commonly used postfixatives that preserve membranes of yeasts are potassium permanganate $\left(\mathrm{KMnO}_{4}\right)$ and osmium tetroxide $\left(\mathrm{OsO}_{4}\right)$. Potassium permanganate has been extensively used as a fixative for EM from 1956 (Luft, 1956). To visualize the ultrastructure of cell membranes and membrane profile of organelles (such as mitochondria, endoplasmic reticulum, nucleus, vacuole, Golgi and endosomes), extraction of cytoplasmic components from aldehyde-fixed cells via incubation with $\mathrm{KMnO}_{4}(0.5$ to $6 \%$ for 1 to $24 \mathrm{~h})$ is recommended (Baharaeen and Vishniac, 1982; Wright and Rine, 1989; Lum and Wright, 1995; Tronchin and Bouchara, 2006). By depositing $\mathrm{MnO}_{2}$, the membranes appear to be also highly contrasted (Sipiczki, 2016). Despite the fact that permanganate fixation is strongly advised for the investigations of complete membrane organization, the fixative does not protect several prominent non membranous cell components such as microfilaments, microtubules or ribosome (Frankl $\boldsymbol{e t}$ al., 2015). Indeed, all that remains are the electron-dense membrane profiles in a consistently gray cytoplasm even after longer incubation period (Wright, 2000). Thus, $\mathrm{KMnO}_{4}$ is sparsely used for internal structure visualization of yeasts.

Osmium tetroxide reacts strongly with unsaturated fatty acids in lipids (changing them to stable glycol osmate; Park $\boldsymbol{e t}$ al., 2016) to provide good fixation of membranous structures and the lipids themselves (Wright, 2000). Due to its high density allowing electron scattering, $\mathrm{OsO}_{4}$ also enhances the contrast of the lipid bilayers visualizing particular membranous compartments (Frankl et al., 2015) Besides this, osmium also reacts with denatured nucleic acids and proteins rich in amino acids with unsaturated double bonds (such as cysteine and tryptophan Park et al., 2016). By contrast, carbohydrates are not preserved by the $\mathrm{OsO}_{4}$ postfixation (Bozzola, 2007). According to many authors (Tronchin and Bouchara, 2006; Osumi, 2012), $\mathrm{OsO}_{4}$ extracts much less material from the cells leading to a visualization of microtubules, microfilaments, ribosomes and chromatin as compared to the $\mathrm{KMnO}_{4}$. However, unlike $\mathrm{KMnO}_{4}$, osmium requires for its good cell penetration either cell wall permeabilization or its complete removal by enzymatic digestion with lytic enzymes (lyticase, zymolyase and glusulase; Wright, 2000). Removing the wall not only facilitates permeation of the embedding resin but also permits the cell to expand slightly, conferring differences in density that provide variation in visual contrast (Byers and Goetsch, 1991). The efficiency of cell wall removal depends primarily on the enzymatic conditions, e.g., the nature of the enzymes, their concentration, and the time and temperature of digestion (Bauer et al., 2001; Požgajová et al., 2017). After enzymatic treatment, the cells are washed and subsequently fixed in 1-2 $\% \mathrm{OsO}_{4}$ in an appropriate buffer, according to the used protocol for time points ranging from 15 to 60 minutes at $4{ }^{\circ} \mathrm{C}$ or room temperature (Wright, 2000).

During prefixation and postfixation processes, the fixed cells die and the released contents of the lysosome can often change the $\mathrm{pH}$ accelerating destruction of macromolecules in the cells (Park et al., 2016). To provide optimal cross-linking and ultimate embedding of the sample, optimal $\mathrm{pH}$ should be maintained by the delivery of prefixatives/postfixatives in buffer solutions. Phosphate, cacodylate or organic based buffers such as PIPES are the most frequently applied. Buffers used for cultivation of yeast cells are typically adjusted to a slightly acidic $\mathrm{pH}$. In addition, they are often supplemented with mineral compounds such as $\mathrm{MgCl}_{2}$ $\mathrm{CaCl}_{2}$, or EGTA (Wright, 2000). For instance, calcium ions added to PIPES and cacodylate buffers are able to improve membrane preservation (Frankl $\boldsymbol{e t} \boldsymbol{a l}$. 2015). Although buffers on phosphate and cacodylate bases are the most commonly employed, it is highly advised to consider the use of organic buffers as a substitution due to their non-destructive effects on fine cell structures and their non-toxicity (Bozzola, 2007).

\section{En Bloc staining}

After complete fixation and several washing steps aimed to remove the fixative residues, cells are treated with $1-2 \%$ aqueous uranyl acetate at room temperature for 30-240 minutes (Wright, 2000) to provide a general background contrast to the sample. Since the contrast in the TEM primarily depends on the electron density differences of the organic molecules in the cells which are usually present in insufficient quantities in fixed samples, the specimens are frequently "poststained" with reagents attaching metals of high atomic mass to the cell structures (such as uranium; Sipiczki, 2016). Indeed, uranyl acetate reacts strongly with phosphate and amino groups leading to staining of nucleic acids and phospholipids in membranes (Kuo, 2007). In addition, uranyl acetate provides some degree of fixation without a major effect on protein conformation (Roque and Antony, 2010)

\section{Dehydration}

Dehydration is the process by which the free water in the fixed sample is replaced by an organic solvent (Winey $\boldsymbol{e t}$ al., 2014). This step is necessary due to water immiscible nature of resins that are used for infiltration and embedding of the samples thus preparing them for the process of sectioning (Sipiczki, 2016). For this purpose, cells are dehydrated by incubation in ascending rates of ethanol (or acetone) concentrations $(25,50,75,95$, and $100 \%$ ) for 5 minutes (or less) in each solution (Wright, 2000). Prior to acetone, ethanol is preferred because it is a more powerful lipid extractor within the cells. Moreover, anhydrous acetone is able to absorb atmospheric water, and it is also efficient radical scavenger, thereby suppressing block polymerization of embedding samples (Sipiczki, 2016).

\section{Infiltration, Embedding and Polymerization (Hardening)}

Embedding is the process of sample infiltration with resins that can be polymerized into a hard plastic material suitable for thin sectioning (Winey et al. 2014). Since ethanol in dehydrated cells is not miscible with embedding media, its replacement by another intermediary solvent with high miscibility with the embedding medium is essential. As a standard transition solvent reducing the embedding media viscosity and thus improving its infiltration into the samples, propylene oxide (PO; 1,2-epoxypropane) is usually used (Sipiczki, 2016). It is common to pass cells for a few minutes through the pure PO prior to infiltration. Then, the cells are pre-infiltrated with various proportions of PO and the embedding medium and after that with the pure embedding medium (Mascorro and Bozzola, 2007)

Two main categories of plastic resins are available for yeast TEM, i.e., epoxy (Araldite, Epon, Spurr's resin) and acrylic (Lowicryl, LR White, LR Gold) resins (Wright, 2000; Frankl et al., 2015; Sipiczki, 2016). Epoxy resins are used for analysis of the cell morphology while acrylic-based resins better preserve the antigenicity of biological samples (Frankl et al., 2015). Epoxy resins can be extensively crosslinked with no impact on their plasticity allowing preparation of the sections as thin as 50-60 $\mathrm{nm}$ (Roque and Antony, 2010), and they also possess excellent poststaining properties (Winey et al., 2014). The resins polymerize at $60{ }^{\circ} \mathrm{C}$ for 24 hours before their ultra-thin sectioning by ultramicrotome (Wright, 2000). On the other hand, the hydrophobic feature of the LR White resin permits the penetration of aqueous solutions containing special antibodies. It can be hardened either by addition of accelerators, heat (Sipiczki, 2016), or UV light which allows its polymerization at very low temperatures $\left(-45\right.$ or $-50{ }^{\circ} \mathrm{C}$; Roque and Antony, 2010).

\section{Thin-sectioning and Staining}

After polymerization, thin sections are cut and mounted on grids for observation in TEM. Generally, thin sectioning (ultramicrotomy) is difficult to acquire sufficient skills. It involves: (i) trimming or shaping the specimen block, (ii) preparing ultramicrotome knives and specimen support grids, (iii) cutting sections on the ultramicrotome, (iv) transferring the sections onto the specimen grid, and (v) staining them to enhance contrast (Bozzola and Russell, 1999) First of all, the block should be trimmed in the way that the section is wide in the parallel axis to the diamond knife and short in the perpendicular axis to the knife. This shape will increase the number of sections per ribbon and allows the search of the same cell across the sections (Roque and Antony, 2010). Once trimmed, the block is mounted in the ultramicrotome that cuts precisely controlled slices over a diamond (or glass) knife edge to produce sections of $\sim 60-80 \mathrm{~nm}$ thickness (Winey et al., 2014). Afterwards, sections floating on the surface of water contained in the trough of the knife are picked on a copper screen mesh, or grid, and stained for contrast using salts of a heavy metal prior to visualization under TEM (Bozzola and Russell, 1999). En bloc stained samples require to be stained only with lead citrate which has the ability to interact with negatively charged components (e.g., hydroxyl groups) or areas reacting to $\mathrm{OsO}_{4}$ (e.g., membranes; Sato, 1968). Since the phosphate buffers usually increase the intensity of staining, lead citrate can also stain the constituents with phosphate groups (Kuo, 2007). After all of the processing steps, dried grids are visualized under TEM.

\section{TRANSMISSION ELECTRON MICROSCOPY AS A UNIQUE TECHNIQUE IN ULTRASTRUCTURAL STUDIES OF SCHIZOSACCHAROMYCES POMBE}

Generally, TEM investigations are necessary for understanding various biological processes (e.g., formation and fusion of vesicles during secretion), cytoskeleton organization, precise mechanisms of biogenesis and degradation of cellular 
organelles, as well as specific localization of certain gene products (Wright, 2000). To ensure maintenance of all cellular requirements, organelles as dynamic and flexible structures are capable of changing their shape and size. Many of these modifications can be observed during normal cell cycle (mitosis, meiosis) or as a part of adaptive mechanism of the cells against environmental stress reflecting alterations in organelle functions (Heald and Cohen-Fix, 2014).

The cell of $S$. pombe contains a minimal number of molecular compounds which is displayed by lower number of subcellular elements (Roque and Antony, 2010). This advantage makes the fission yeast to be a convenient model organism to study the cell ultrastructure using TEM under normal or experimental conditions. The architecture of $S$. pombe was first studied by TEM using $\mathrm{KMnO}_{4}$ and $\mathrm{OsO}_{4}$ as fixatives in 1964 (Maclean, 1964). The serial sectioned TEM images showed 0.1-0.2 $\mu \mathrm{m}$ thick cell wall, cell membrane, central nucleus (2-3 $\mu \mathrm{m}$ in diameter) with granular nucleolus, bounded by double nuclear membrane, and various cytoplasmic structures (vacuoles, membranes and vesicles, and granules). Later, detailed ultrastructure of the cell wall in the $S$. pombe was performed by several researchers (Kopecká et al., 1995; Osumi et al., 1998; Humbel et al., 2001; Sugawara et al., 2003). The cell wall has been recognized as a triple-layered structure involving two electron dense layers (outer one and a layer bordering the cell membrane) separated by an adjacent less dense layer with fine branched filamentous structures. In the fission yeast, TEM has also been used as a unique tool for examination of mitotic and meiotic events. First visualization of mitosis in $S$. pombe using TEM was performed by McCully and Robinow (1971). In this study, the presence of disk-shaped electron-dense organelles, specifically called as kinetochore equivalents (KCEs) was revealed. Further studies with $S$. pombe have utilized TEM to visualize the septum of dividing cells (Humbel et al., 2001), nuclear division during mitosis (Tanaka and Kanbe, 1986), fusion and erosion of cell walls during conjugation (Calleja et al., 1977), nuclear envelope during first and second anaphase (Asakawa et al., 2010), ascospore formation (Yoo et al., 1990; Asakawa et al., 2001), ultrastructural alterations in mitochondria morphology during division of the organelle (Osumi and Sando, 1969), dynamics of cytoplasmic structures (vesicles, filasomes, microfilament, and microfilament-associated granules, dictyosomes) in the cell cycle (Kanbe et al., 1989), and dynamics of cell membrane and/or cellular structures (mainly the Golgi apparatus and the secretory vesicles) during de novo synthesis of cell wall in reverting protoplas (Naito et al., 1991; Osumi et al., 1998; Takagi et al., 2003).

Moreover, TEM has also been used in ultrastructural studies of $S$. pombe unde defined environmental conditions. In the study by Amoah-Buahin et al. (2005) the ultrastructure of hyphal growth forms of wild-type $S$. pombe initiated in consequence of nitrogen starvation was investigated. Ayscough et al. (1993) have reported damage of the microtubular system leading to separation of Golgi apparatus cisternae in $S$. pombe treated with anti-microtubule agent thianedazole Following this study, S. pombe may be used as a unique model for study of ultrastructural changes in the cells due to toxic impact of various substances Moreover, since it shares similarities with many fundamental biological processes occurring in higher eukaryotic organisms (e.g., mRNA splicing, posttranslational modifications as $\mathrm{N}$-glycosylation protein, cell-cycle regulation, cAMP-PKA pathway, autophagy, nutrient-sensing pathways as the target of rapamycin - TOR pathway; Rosas-Murrieta et al., 2015), the same ultrastructural alterations in $S$. pombe cells induced by various exogenous factors (such as the impact of environmental contamination) can be expected also in higher organisms (including humans). Thus, the use of fission yeast $S$. pombe as a model organism for ultrastructural studies may bring a new knowledge in the process, progress or regulation of various biological processes with the direct application to mammalian cells including human.

In our laboratory, the methods of conventional preparation of $S$. pombe for TEM are being introduced. The TEM technique will provide additional information about ultrastructural changes in the cells due to the effect of environmental stress (heavy metals). However, our preliminary results (not yet published) indicate that optimization of the process is still necessary. Indeed, the key step for precise preservation of cellular structure by fixatives requires a sufficient cell wall removal by the action of enzymes. The concentration, as well as the incubation time for zymolyase treatment is now optimized to obtain more relevant ultrastructure of the $S$. pombe cells with well-contrasted cell membranes and compartments.

\section{CONCLUSION}

Transmission electron microscopy is a powerful and very precise technique to study morphological structures such as surface features, shape, size or ultrastructure of biological samples and their organelles. In general, $S$. pombe is a popular model system used for characterization of basic eukaryotic processes at cellular and molecular levels. Studies performed on a convenient model system (such as the fission yeast) using TEM allow scientists to analyze cytoskeleton organization, the mechanisms of organelle biogenesis and degradation, and ultrastructure and dynamics of organelles as a consequence of adaptive mechanisms against various exogenous factors. As a unique model system, $S$. pombe can also be used in ultrastructural studies evaluated the toxic effects of environmental pollution on cell ultrastructure. Since it shares many essentia biochemical, molecular and genetic characteristics with higher eukaryotic organisms, the same ultrastructural alterations found in $S$. pombe cells might also be expected in higher organisms (including humans). However, to achieve results with such noticeable value it is of great importance to lay stress on very accurate sample preparation. Moreover, the exact data interpretation is essential for correct definition of obtained results and conclusion presentation.

Altogether, ultrastructural analyses performed with a single-celled eukaryotic organism have the power to bring new insights to the changes in the behavior of organisms to various challenges of its living conditions on cellular and subcellular level that can be to a large extent transformed to higher biological systems.

Acknowledgments: This research was supported by European Community under project No. 26220220180: Building Research Centre "AgroBioTech and by the Scientific Agency of the Slovak Republic VEGA No. 1/0163/18, APVV-150543 .

\section{REFERENCES}

AL-WATTAR, A. W. 2017. Model systems in biological research. Journal of Cell Biology and Metabolism, 1(1), 1.

AMOAH-BUAHIN, E., BONE, N., ARMSTRONG, J. 2005. Hyphal growth in the fission yeast Schizosaccharomyces pombe. Eukaryotic cell, 4(7), 1287-1297. http://dx.doi.org/10.1128/EC.4.7.1287-1297.2005

ANKENY, R. A., LEONELLI, S. 2011. What's so special about model organisms? Studies in History and Philosophy of Science Part A, 42(2), 313-323. https://dx.doi.org/10.1016/j.shpsa.2010.11.039

ASAKAWA, H., KITAMURA, K., SHIMODA, C. 2001. A novel Cdc20-related WD-repeat protein, Fzr1, is required for spore formation in Schizosaccharomyces pombe.Molecular Genetics and Genomics, 265(3), 424-435. https://dx.doi.org/10.1007/s004380000429

ASAKAWA, H., KOJIDANI, T., MORI, C., OSAKADA, H., SATO, M., DING D. Q., HIRAOKA, Y. HARAGUCHI, T. 2010. Virtual breakdown of the nuclear envelope in fission yeast meiosis. Current Biology,20(21), 1919-1925. https://dx.doi.org/10.1016/j.cub.2010.09.070

ASAKAWA, H., HIRAOKA, Y., HARAGUCHI, T. 2012. Live CLEM imaging: an application for yeast cells. Current microscopy contributions to advances in science and technology, 1, 478-485.

AYSCOUGH, K., HAJIBAGHERI, N. M., WATSON, R., WARREN, G. 1993 Stacking of Golgi cisternae in Schizosaccharomyces pombe requires intact microtubules. Journal of cell science, 106(4), 1227-1237.

AYUB, B., WANI, H., SHOUKAT, S., PARA, P. A., GANGULY, S., ALI, M

2017. Specimen preparation for electron microscopy: an overview. Journal of Environment and Life Sciences, 2(3), 85-88.

BAHARAEEN, S., VISHNIAC, H. S. 1982. A fixation method for visualization of yeast ultrastructure in the electron microscope. Mycopathologia, 77(1), 19-22. https://dx.doi.org/10.1007/BF00588651

BAUER, C., HERZOG, V., BAUER, M. F. 2001. Improved technique for electron microscope visualization of yeast membrane structure. Microscopy and Microanalysis, 7(6), 530-534. https://dx.doi.org/10.1017.S1431927601010522

BENITO, Á., JEFFARES, D., PALOMERO, F., CALDERÓN, F., BAI, F. Y. BÄHLER, J., BENITO, S. 2016. Selected Schizosaccharomyces pombe strains have characteristics that are beneficial for winemaking. PloS one, 11(3), e0151102. https://dx.doi.org/10.1371/journal.pone.015110

BÖTTCHER, B. 2012. Transmission electron microscopy: Preparation of specimens. In: eLS. John Wiley \& Sons Ltd, Chichester, 1-9 p. https://dx.doi.org/10.1002/9780470015902.a0002998.pub2

BOZZOLA, J. J., RUSSELL, L. D. 1999. Electron microscopy: principles and techniques for biologists. $2^{\text {nd }}$ edition, Boston: Jones \& Bartlett Learning, $670 \mathrm{p}$ ISBN 0763701920

BOZZOLA, J. J. 2007. Conventional specimen preparation techniques for transmission electron microscopy of cultured cells. In Kuo, J. (ed.): Electron Microscopy: Methods and protocols, $2^{\text {nd }}$ edition, Totowa: Humana Press, 1-18 p. ISBN 13: 978-1-58829-573-6

BYERS, B., GOETSCH, L. 1991. Preparation of yeast cells for thin-section electron microscopy. Methods in enzymology, 194, 602-608. https://dx.doi.org/10.1016/0076-6879(91)94044-D

CALLEJA, G. B., YOO, B. Y., JOHNSON, B. F. 1977. Fusion and erosion of cell walls during conjugation in the fission yeast (Schizosaccharomyces pombe). Journal of cell science, 25(1), 139-155.

FORSBURG, S. L., RHIND, N. 2006. Basic methods for fission yeast. Yeast, 23(3), 173-183. https://dx.doi.org/10.1002/yea.1347

FRANKL, A., MARI, M., REGGIORI, F. 2015. Electron microscopy for ultrastructural analysis and protein localization in Saccharomyces cerevisiae. Microbial Cell, 2(11), 412-428. https://dx.doi.org/10.15698/mic2015.11.237

GIDDINGS, T. H., MORPHEW, M. K., MCINTOSH, J. R. 2017. Preparing fission yeast for electron microscopy. Cold Spring Harbor Protocols, 2017(1), pdb-prot091314. https://dx.doi.org/10.1101/pdb.prot091314 
GOMES, F. C., PATARO, C., GUERRA, J. B., NEVES, M. J., CORREAA, S. R., MOREIRA, E. S., ROSA, C. A. 2002. Physiological diversity and trehalose accumulation in Schizosaccharomyces pombe strains isolated from spontaneous fermentations during the production of the artisanal Brazilian cachaça. Canadian journal of microbiology, 48(5), 399-406. https://dx.doi.org/10.1139/w02-032 GÓMEZ, E. B., FORSBURG, S. L. 2004. Analysis of the fission yeast Schizosaccharomyces pombe cell cycle. In: Lieberman, H. B.: Cell Cycle Checkpoint Control Protocols. Methods in Molecular Biology ${ }^{\mathrm{TM}}$, vol. 241, Totowa: Humana Press, 93-111 p. ISBN 978-1-58829-115-8

GRÜN, C. H., HOCHSTENBACH, F., HUMBEL, B. M., VERKLEIJ, A. J., SIETSMA, J. H., KLIS, F. M., KAMERLING, J. P., VLIEGENTHART, J. F. G. 2004. The structure of cell wall $\alpha$-glucan from fission yeast. Glycobiology, 15(3), 245-257. https://dx.doi.org/10.1093/glycob/cwi002

HAGAN, I. M., GRALLERT, A., SIMANIS, V. 2016. Analysis of the Schizosaccharomyces pombe cell cycle. Cold Spring Harbor Protocols, 2016(9), pdb-top082800. https://dx.doi.org/10.1101/pdb.top082800

HAJIBAGHERI, M. A. N., SAWIN, K., GSCHMEISSNER, S., BLIGHT, K., UPTON, C. 1999. Preparation of the fission yeast Schizosaccharomyces pombe for ultrastructural and immunocytochemical study. In: Hajibagheri, M. A. N (ed.): Electron Microscopy Methods and Protocols, Totowa: Humana Press, 183207

HAYLES, J., NURSE, P. 2018. Introduction to fission yeast as a model system. Cold Spring Harbor Protocols, 2018(5), pdb-top079749. https://dx.doi.org/10.1101/pdb.top079749

HEALD, R., COHEN-FIX, O. 2014. Morphology and function of membranebound organelles. Current opinion in cell biology, 26, 79-86. https://dx.doi.org/10.1016/j.ceb.2013.10.006

HOFFMAN, C. S., WOOD, V., FANTES, P. A. 2015. An ancient yeast for young geneticists: a primer on the Schizosaccharomyces pombe model system. Genetics, 201(2),

https://dx.doi.org/10.1534/genetics.115.181503

HUANG, T. Y., MARKLEY, N. A., YOUNG, D. 2003. Nak1, an essential germinal center (GC) kinase regulates cell morphology and growth in Schizosaccharomyces pombe. Journal of Biological Chemistry, 278(2), 991-997. https://dx.doi.org/10.1074/jbc.M208993200

HUMBEL, B. M., KONOMI, M., TAKAGI, T., KAMASAWA, N., ISHIJIMA, S. A., OSUMI, M. 2001. In situ localization of $\beta$-glucans in the cell wall of Schizosaccharomyces https://dx.doi.org/10.1002/yea.694

KANBE, T., KOBAYASHI, I. S. S. E. I., TANAKA, K. E. N. J. I. 1989 Dynamics of cytoplasmic organelles in the cell cycle of the fission yeast Schizosaccharomyces pombe: three-dimensional reconstruction from serial sections. Journal of Cell Science, 94(4), 647-656.

KARNOVSKY, M. J. 1964. The localization of cholinesterase activity in rat cardiac muscle by electron microscopy. The Journal of cell biology, 23(2), 217 232. https://dx.doi.org/10.1083/jcb.23.2.217

KIERNAN, J. A. 2000. Formaldehyde, formalin, paraformaldehyde and glutaraldehyde: what they are and what they do. Microscopy today, 8(1), 8-13 https://dx.doi.org/10.1017/S1551929500057060

KOCH, A., BICHO, C. C., BOREK, W. E., CARPY, A., MAČEK, B., HAUF, S., SAWIN, K. E. 2017. Construction, growth, and harvesting of fission yeast stable isotope labeling by amino acids in cell culture (SILAC) Strains. Cold Spring Harbor Protocols, 2017(6), pdb-prot091678. https://dx.doi.org/10.1101/pdb.prot091678

KOPECKA, M., FLEET, G. H., PHAFF, H. J. 1995. Ultrastructure of the cell wall of Schizosaccharomyces pombe following treatment with various glucanases. Journal of structural biology, 114(2), 140-152. https://dx.doi.org/10.1006/jsbi.1995.1013

KOVACIKOVA, I., POLAKOVA, S., BENKO, Z., CIPAK, L., ZHANG, L. RUMPF, C., MIADOKOVA, E., GREGAN, J. 2013. A knockout screen for protein kinases required for the proper meiotic segregation of chromosomes in the fission yeast Schizosaccharomyces pombe. Cell Cycle, 12(4), 618-624. https://dx.doi.org/10.4161/cc.23513

KOVAR, D. R., SIROTKIN, V., LORD, M. 2011. Three's company: the fission yeast actin cytoskeleton. Trends in cell biology,21(3), 177-187. https://dx.doi.org/10.1016/j.tcb.2010.11.001

KUO, J. 2007. Processing plant tissues for ultrastructural study. In: Kuo, J. (ed.): Electron microscopy: methods and protocols. $2^{\text {nd }}$ edition, Totowa: Humana Press, 35-46. ISBN 13: 978-1-58829-573-6

de LEON, N., SHARIFMOGHADAM, M. R., HOYA, M., CURTO, M. A., DONCEL, C., VALDIVIESO, M. H. 2013. Regulation of cell wall synthesis by the clathrin light chain is essential for viability in Schizosaccharomyces pombe. PloS one, $8(8)$,

e71510. https://dx.doi.org/10.1371/journal.pone.0071510

LIN, S. J., AUSTRIACO, N. 2014. Aging and cell death in the other yeasts, Schizosaccharomyces pombe and Candida albicans. FEMS yeast research, 14(1), 119-135. https://dx.doi.org/10.1111/1567-1364.12113

LUFT, J. H. 1956. Permanganate- a new fixative for electron microscopy. The Journal of biophysical and biochemical cytology,2(6), 799. https://dx.doi.org/10.1083/jcb.2.6.799
LUM, P. Y., WRIGHT, R. 1995. Degradation of HMG-CoA reductase-induced membranes in the fission yeast, Schizosaccharomyces pombe. The Journal of cell biology, 131(1), 81-94. https://dx.doi.org/10.1083/jcb.131.1.81

MACLEAN, N. 1964. Electron microscopy of a fission yeast, Schizosaccharomyces pombe. Journal of bacteriology, 88(5), 14591466

MANNERS, D. J., MEYER, M. T. 1977. The molecular structures of some glucans from the cell walls of Schizosaccharomyces pombe. Carbohydrate research, 57, 189-203. https://dx.doi.org/10.1016/S0008-6215(00)81930-8

MASCORRO, J. A., BOZZOLA, J. J. 2007. Processing biological tissues for ultrastructural study. In Kuo, J. (ed.): Electron microscopy: methods and protocols. 2nd edition, Totowa: Humana Press, 19-34. ISBN 13: 978-1-58829573-6

MARTÍN, R., BERLANGA, J. J., de HARO, C. 2013. New roles of the fission yeast eIF2 $\alpha$ kinases Hri1 and Gen2 in response to nutritional stress. Journal of Cell Science, 126(Pt 14), 3010-3020. https://dx.doi.org/10.1242/jcs.118067

McCULLY, E. K., ROBINOW, C. 1971. Mitosis in the fission yeast Schizosaccharomyces pombe: a comparative study with light and electron microscopy. Journal of Cell Science, 9(2), 475-507.

MIELANCZYK, Ł., MATYSIAK, N., KLYMENKO, O., WOJNICZ, R. 2015. Transmission Electron Microscopy of Biological Samples. In Maaz, K. (ed.): The Transmission Electron Microscope: Theory and Applications. InTech, 193-239 p. ISBN 978-953-51-2150-3

MULHOLLAND, J., BOTSTEIN, D. 2002. Immunology microscopy of aldehyde-fixed yeast cells. Methods in enzymology, 351, 50-81. https://dx.doi.org/10.1016/S0076-6879(02)51841-3

NAITO, N., YAMADA, N., KOBORI, H., OSUMI, M. 1991. Contrast enhancement by ruthenium tetroxide for observation of the ultrastructure of yeast cells. Microscopy, 40(6),

https://dx.doi.org/10.1093/oxfordjournals.jmicro.a050919

OSUMI, M., SANDO, N. 1969. Division of yeast mitochondria in synchronous culture. Microscopy, 18(1),

https://dx.doi.org/10.1093/oxfordjournals.jmicro.a049643

OSUMI, M., SATO, M., ISHIJIMA, S. A., KONOMI, M., TAKAGI, T. YAGUCHI, H. 1998. Dynamics of cell wall formation in fission yeast, Schizosaccharomyces pombe. Fungal Genetics and Biology, 24(1-2), 178-206. https://dx.doi.org/10.1006/fgbi.1998.1067

OSUMI, M. 2012. Visualization of yeast cells by electron microscopy. Journal of electron microscopy, 61(6), 343-365. https://dx.doi.org/10.1093/jmicro/dfs082 ÖZEN, A., CEYLAN, A. 2013. General principles of electron microscopy preparation protocol. Niche, 1, 5-8. https://dx.doi.org/10.5152/niche.2014.131 PARK, C. H., KIM, H. W., UHM, C. S. 2016. How to get well-preserved samples for transmission electron microscopy. Applied Microscopy, 46(4), 188192. https://dx.doi.org/10.9729/AM.2016.46.4.188

PECKYS, D. B., MAZUR, P., GOULD, K. L., de JONGE, N. 2011. Fully hydrated yeast cells imaged with electron microscopy. Biophysical journal, 100(10), 2522-2529. https://dx.doi.org/10.1016/j.bpj.2011.03.045

PERKINS, E. M., McCAFFERY, J. M. 2007. Conventional and immunoelectron microscopy of mitochondria. Mitochondria, 372, 467-483. https://dx.doi.org/10.1007/978-1-59745-365-3 33

PETERSEN, J., RUSSELL, P. 2016. Growth and the environment of Schizosaccharomyces pombe. Cold Spring Harbor Protocols, 2016(3), pdbtop079764. https://dx.doi.org/10.1101/pdb.top079764

PÉREZ, P., RIBAS, J. C. 2017. Fission yeast cell wall analysis. Cold Spring Harbor Protocols, 2017(11), pdb.top079897. https://dx.doi.org/10.1101/pdb.top079897

PIEL, M., TRAN, P. T. 2009. Cell shape and cell division in fission yeast. Current Biology, 19(17),

https://dx.doi.org/10.1016/j.cub.2009.08.012

POZGAJOVA, M., CIPAK, L., TRAKOVICKA, A. 2013. Prp4 kinase is required for proper segregation of chromosomes during meiosis in Schizosaccharomyces pombe. Acta Biochimica Polonica, 60(4), 871-873. https://dx.doi.org/10.18388/abp.2013_2075

POŽGAJOVÁ, M., NAVRATILOVA, A., TRAKOVICKA, A. 2017. Determination of the efficient enzyme concentration for lytic digestion of vegetative cells but not spores in Schizosaccharomyces pombe. Acta Fytotechnica et Zootechnica, 20(2), 20-22. https://dx.doi.org/10.15414/afz.2017.20.01.20-22

ROQUE, H., ANTONY, C. 2010. Fission yeast: A cellular model well suited for electron microscopy investigations. Methods in cell biology, 96, 235-58. https://dx.doi.org/10.1016/S0091-679X(10)96011-1

ROSAS-MURRIETA, N. H., ROJAS-SÁNCHEZ, G., REYES-CARMONA, S R., MARTÍNEZ-CONTRERAS, R. D., MARTÍNEZ-MONTIEL, N., MILLÁNPÉREZ-PEÑA, L., HERRERA-CAMACHO, I. P. 2015. Study of cellular processes in higher eukaryotes using the yeast Schizosaccharomyces pombe as a model. In: Shah, M. M. (ed.): Microbiology in Agriculture and Human Health. InTech, 107-132. ISBN 978-953-51-2144-2

SATO, T. 1968. A modified method for lead staining of thin sections. Microscopy, 17(2),

https://dx.doi.org/10.1093/oxfordjournals.jmicro.a049610 
SIPICZKI, M. 2016. Visualization of fission yeast cells by transmission electron microscopy. In: Sanchez-Diaz, A., Perez, P. (eds.): Yeast Cytokinesis: Methods and Protocols. New York: Humana Press, 97-111 p. ISBN 978-1-4939-3144-6

SLAYTER, E. M., SLAYTER, H. S. 1992. Light and electron microscopy. Cambridge University Press, 312 p. ISBN 0-521-32714-8

SUGAWARA, T., SATO, M., TAKAGI, T., KAMASAKI, T., OHNO, N., OSUMI, M. 2003. In situ localization of cell wall $\alpha-1,3$-glucan in the fission yeast Schizosaccharomyces pombe. Microscopy, 52(2), 237-242.

TAKAGI, T., ISHIJIMA, S. A., OCHI, H., OSUMI, M. 2003. Ultrastructure and behavior of actin cytoskeleton during cell wall formation in the fission yeast Schizosaccharomyces pombe. Microscopy, 52(2), 161-174.

TANAKA, K., KANBE, T. 1986. Mitosis in the fission yeast Schizosaccharomyces pombe as revealed by freeze-substitution electron microscopy. Journal of cell science, 80(1), 253-268.

TRONCHIN, G., BOUCHARA, J. 2006. Transmission electron microscopy of pathogenic fungi. In: Kavanagh, K. (ed.): Medical Mycology: Cellular and Molecular Techniques. John Wiley \& Sons, Ltd. 13-41 p. ISBN 978-0-47001923-8

VOLSCHENK, H., van VUUREN, H. J. J., VILJOEN-BLOOM, M. 2003. Maloethanolic fermentation in Saccharomyces and Schizosaccharomyces. Current genetics, 43(6), 379-391. https://dx.doi.org/10.1007/s00294-003-0411-6

WINEY, M., MEEHL, J. B., O'TOOLE, E. T., GIDDINGS, Jr., T. H. 2014

Conventional transmission electron microscopy. Molecular biology of the cell, 25(3), 319-323. https://dx.doi.org/10.1091/mbc.E12-12-0863

WOOD, V., GWILLIAM, R., RAJANDREAM, M. A., LYNE, M., LYNE, R., STEWART, A., SGOUROS, J., PEAT, N., HAYLES, J., BAKER, S., BASHAM, D., BOWMAN, S., BROOKS, K., BROWN, D., BROWN, S., CHILlingWORTH, T., CHURCHER, C., COLlINS, M., CONNOR, R. CRONIN, A., DAVIS, P., FELTWELL, T., FRASER, A., GENTLES, S., GOBLE, A., HAMLIN, N., HARRIS, D., HIDALGO, J., HODGSON, G., HOLROYD, S., HORNSBY, T., HOWARTH, S., HUCKLE, E. J., HUNT, S., JAGELS, K., JAMES, K., JONES, L., JONES, M., LEATHER, S., MCDONALD, S., MCLEAN, J., MOONEY, P., MOULE, S., MUNGALL, K., MURPHY, L., NIBLETT, D., ODELL, C., OLIVER, K., O'NEIL, S., PEARSON, D., QUAIL, M. A., RABBINOWITSCH, E., RUTHERFORD, K., RUTTER, S., SAUNDERS, D., SEEGER, K., SHARP, S., SKELTON, J., SIMMONDS, M., SQUARES, R., SQUARES, S., STEVENS, K., TAYLOR, K., TAYLOR, R. G., TIVEY, A., WALSH, S., WARREN, T., WHITEHEAD, S., WOODWARD, J., VOLCKAERT, G., AERT, R., ROBBEN, J., GRYMONPREZ, B., WELTJENS, I., VANSTREELS, E., RIEGER, M., SCHÄFER, M., MÜLLER-AUER, S., GABEL, C., FUCHS, M., DÜSTERHÖFT, A., FRITZC, C., HOLZER, E., MOESTL, D., HILBERT, H. BORZYM, K., LANGER, I., BECK, A., LEHRACH, H., REINHARDT, R., POHL, T. M., EGER, P., ZIMMERMANN, W., WEDLER, H., WAMBUTT, R., PURNELlE, B., GOFFEAU, A., CADIEU, E., DRÉANO, S., GLOUX, S., LELAURE, V., MOTTIER, S., GALIBERT, F., AVES, S. J., XIANG, Z., HUNT, C., MOORE, K., HURST, S. M., LUCAS, M., ROCHET, M. GAILlARDIN, C., TALlADA, V. A., GARZON, A., THODE, G., DAGA, R. R., CRUZADO, L., JIMENEZ, J., SÁNCHEZ, M., DEL REY, F., BENITO, J., DOMÍNGUEZ, A. REVUELTA, J. L. MORENO, S. ARMSTRONG, J., FORSBURG, S. L., CERUTTI, L., LOWE, T., MCCOMBIE, W. R., PAULSEN, I., POTASHKIN, J., SHPAKOVSKI, G. V., USSERY, D., BARRELL, B. G., NURSE, P. 2002. The genome sequence of Schizosaccharomyces pombe. Nature, 415(6874), 871-880. https://dx.doi.org/10.1038/nature724

WRIGHT, R., RINE, J. 1989. Transmission electron microscopy and immunocytochemical studies of yeast: analysis of $\mathrm{HMG}-\mathrm{CoA}$ reductase overproduction by electron microscopy. Methods in cell biology, 31, 473-512. https://dx.doi.org/10.1016/S0091-679X(08)61624-6

WRIGHT, R. 2000. Transmission electron microscopy of yeast. Microscopy research and technique, 51(6), 496-510. https://dx.doi.org/10.1002/1097. 0029(20001215)51:6<496::AID-JEMT2>3.0.CO;2-9

YAMASHITA, A., SAKUNO, T., WATANABE, Y., YAMAMOTO, M. 2017. Live imaging of chromosome segregation during meiosis in the fission yeast Schizosaccharomyces pombe. Cold Spring Harbor Protocols, 2017(9), pdbprot091769. https://dx.doi.org/10.1101/pdb.prot091769

YANAGIDA, M. 2002. The model unicellular eukaryote, Schizosaccharomyces pombe. Genome biology, 3(3), comment2003-1. 10.1186/gb-2002-3-3comment2003. https://dx.doi.org/10.1186/gb-2002-3-3-comment2003

YOO, B. Y., JOHNSON, B. F., CALLEJA, G. B. 1990. Ultrastructure of the ascospore walls of Schizosaccharomyces pombe during germination. Mycologia, 82(1), 43-47. https://dx.doi.org/10.1080/00275514.1990.12025839

ZHAO, R. Y. 2017. Yeast for virus research. Microbial Cell, 4(10), 311-330. https://dx.doi.org/10.15698/mic2017.10.592 